Jusmal llmial

PFUR AT DE

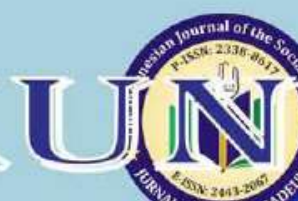

Vol. 5, No. 3, September 2017

$\int_{\substack{\text { Indrjesident } \\ \text { si in }}} 1$

sCAD Intependent Acreditatiou by 100 since 2014 $\bigodot$ Copernicus Publications

\section{JIP}

The Indonesian Journal of the Social Sciences www.journal.scadindependent.ors D01 Prefix Number; 10,26811
Csinta

INDEX COPERNICUS 


\title{
SPIRITUAL CULTURE OF BANJAR SULTANATE (Historical, Hermeneutic and Educational Approach)
}

\section{Kamrani Buseri}

Antasari State Islamic University, Indonesia

Contributor Email:kamrani2505@gmail.com

\begin{abstract}
Culture and education are interconnected. If culture is to be preserved, transformed and transferred from one generation to the next, education in its broader sense is the key process of doing so. Each society or community group has its own culture as its distinctive characteristics. This culture contains values by which members of the society abide. Since the establishment of Banjar Sultanate in 1526, the Banjarese have developed spiritual culture which is reflected in material forms such as in houses shapes, process of cultivating rice in the paddy field, and other daily traditions. Besides, spiritual culture is also manifested in educational institution as well as in the attitude of its educators. As of today, these cultural values are still relevant to be developed, because they may become foundation of social behavior, especially for younger generation who are prone to influences of secularism, hedonism, and pragmatism.
\end{abstract}

Keywords: Culture, Spiritual Culture, Banjar Sultanate, Education 


\section{A. Introduction}

Education has never been out of the culture, because one of the functions of education, in addition to transfer of knowledge and skills, is also to transfer cultural values. Even education preserves, transforms, develops, and changes culture.

Culture can be reflected in physical or material forms spiritual forms. Edward Tylor, father of modern anthropology, in his Primitive Culture, defined culture, taken in its wide ethnographic sense, is that complex whole which includes knowledge, belief, art, morals, law, custom, and any other capabilities and habits acquired by man as a member of society. This implies that there are two conceptions of culture. One was the material culture rooted in primitive life and the other the spiritual culture reflected in such human creations as art, literature, philosophy, and religion. Therefore we know both the material culture and spiritual culture. While the essences of culture are values with which society abide and comply. As the case of Banjarese culture, because the Banjarese people are mostly Muslims their cultural outlook is heavily influenced by their Islamic belief (See Edward Tylor, 1920: 20-70).

Historically, ever since the Sultanate of Banjar was established, the spiritual culture had flourished with direct or indirect support from the court house. Despite its Hindu past, the Banjarese culture is now mainly Islamic or inspired by Islam. This Islam-based culture is not only visible in the physical forms, but also in the spiritual forms.

In its physical forms, the culture of the Islamic Banjarese Sultanate can be seen in buildings and their structures of mosques, madrasahs, and Islamic boarding schools (pesantrens). These physical forms of culture of the Banjarese Sultanate function as the main instruments for the development of the spiritual culture. Therefore, these two-side of a coin form of culture should be maintained by modifying and reconstructing ti so as to be instrumental in the maintenance of social culture in this contemporary era.

To mention some of the importance of Islamic belief practiced by the sultans of Banjar in their material and spiritual culture is Batamat Quran (the 
completion of Quran reading) with each and every activity and thing around it. The Banjarese are well known for their religiousity, their high ability in reciting the Holy Quran, and their competence in Arabic reading Arabic scripts. The competence of the Banjarese in Arabic script reading was once mentioned by former minister of Religious Affairs, A. Mukti Ali. He is of the opinion that Banjarese Islamic scholars have high competence in Arabic. This can be said as symbol of high spiritual culture.

This study is about spiritual culture of Banjar Sultanate viewed historically, hermeneutically and educationally. Historical approach is used to look at the historical development of Banjarese society and culture since its conception up to its contemporary state. Hermeneutic approach is to see the meanings of a myriad of artifacts, symbols, nomenclatures, and Muslim scholars' attitude and people's attitude towards the Muslim scholars. All of these will help us in understanding all of the meanings and views on Banjarase culture.

\section{B. Banjarese Society and Their Culture}

Alfani Daud claimed that thousands of years ago a faction of Malayic people from Sumatra emigrated to the Island of Borneo (Kalimantan). These people made up the core element of the contemporary Banjarese people (Daud, 1997: 25). Daud (1997:34) further said that the Banjarese could be divided into two sub-ethnics, Down-river Banjarese, who live along the sides of river systems, and Upriver Banjarese, who live in the foot hills of Meratus mountain. Regardless of their settlement types, both of them share similar characteristics, they are Muslims and speak Banjarese with slightly different dialects in morphology and phonology.

The extent of identification of the Banjarese as Muslims has led to a conclusion that non-Banajarese people of southeastern Borneo, such as Ngaju people of Marabahan who converted to Islam in the 19th century are now identified as Banjarese (Daud, 1997:34). Ghazali Usman claimed that Banjarese were conceived rather coincidentally with the establishment of Banjarese Sultanate in 1526 in Bandarmasih, former name of modern Banjarmasin. The Sultanate was established by Prince Samudra, the ousted 
crown-prince of Hindu kingdom of Negaradaha. In the process of establishing the kingdom, Prince Samudra had military support from Javanese Islamic kingdom of Demak. Upon his victory, he moved the center of the kingdom down-river to Banjarmasin in the estuary of great Barito River. The prince then converted to Islam and changed his name to Suriansyah with the title of Sultan. Along with his the new king's conversion to Islam, most of his people also converted. It is this mixture of ethnics, the Javanese, Ngaju, and Banjarse, that formed the core of Banjarese ethnicity (Analiansyah dkk., 2007: 7-8).

However, Gt. Abdul Muis said that Islam had come to south Kalimantan around the beginning of the 16th century. It was broght by merchant-cum-preacher from north coast of East Java (Analiansyah dkk., 2007: 8). Islam had been the religion of some people living in the estuary of the great Barito River prior to the establishment of Banjarase sultanate.

Although the majority of people in the sultanate were Muslims, Islamic teachings had not been practice by these newly converted muslims. Upon his return from Mecca, Syekh Muhammad Arsyad al-Banjari started a well-planned, systematic, and massive efforts to preach and teach Islamic principles to the Banjarese people. He tried to get rid of elements of animism, Hinduism, and Buddhism from religious practices of the Banjarese muslims. Some of his systematic efforts include writing some books on Islamic jurisprudence, theology, and sufism. Many of his works have been widely read and used by, especially, Malay muslims in the southeast asian archipelago. Considering the influence and the contents of Al-Banjari's works in theololgy, jurisprudence, and sufism it is conclusive that his school of thought is Ahlussunnah wal Jama'ah and is under heavy influence of Shafi' $i$ school of jurisprudence ((Analiansyah dkk., 2007: 10-11). This school of thought is now distinctive in the life of Banjarese people.

\section{Manifestations of Banjarese Sipiritual Culture}

M. Rifhan wrote in local newspaper Harian Media Kalimantan of November 28, 2011 issue saying that traditional Banjarese houses are built on the concepts of Banjarese culture which is religiously and 
philosophically rich in meanings. The towering ridge of the traditional houses reflects the belief of God's omnipresence and omnipotence. The upper part of the traditional Banjarese houses, a five-pointed shape of structure, is a manifestation of five basic principles of Islam. All measurements of height, width, and length are odd in numbers so they copy the odd number of attributes and names of God. In addition, the ornaments of the houses on stilts are also meant to reflect a balanced and harmonious relation of man, nature, and the Creator.

In addition to its manifestations in physical and structural aspects, spiritual culture also manifests itself in the cycles of life of the Banjarese. It is especially visible in the rites of passage; birth-marriage-death. With regards to the first rite of passage, the Banjarese celebrate rituals of the seventh month of pregnancy, batapung tawar (prayers offered upon the birth of a baby and baby naming ceremony), batumbang (the first day for the child to step on a groud or dirt), and ba-ayun anak (swinging a child in a fabric cradle). In all of these practices Islamic teachings are clearly visible.

Aspect of spiritual culture can also be seen in the daily activity of the Banjarese. Most of Banjarese are paddy farmers, therefore their main staple mainly consists of rice. Throughout the phases of rice cultivation, the Banjarese always relate them with spirituality. In the seedling phase, prior to planting the seed on the ground, the Banjarese farmers perform merabun ritual, that is to pass the seed over burning incense and offer some prayers. When putting the seed on the water to sprout, the first chapter of the Holy Qur'an, al-Fatihah, is recited once, and prayers as well as blessing to Prophet Muhammad, is offered three times. In the process of putting the sprouting seed to the ground, various supplications are also read.

The treatment of paddy as a divine gift from the Almighty God continues to the process of harvesting and consuming it. Prior to harvesting it, prayers and mantra kuur sumangat (literally means come over here o spirit) are offered to summon the spirit of the rice (Daud, 1997). In so doing, the Banjarese practice the belief that rice has some kind of spirit in their life. However, such practice has started to be abandoned by younger generation. 


\section{Infiltration of Secular and Pragmatic Culture}

As citizens of the so-called global village, the Banjarese cannot avoid themselves from the influences of other cultures and development taking place in other parts of the world. For examples, infiltration of secularism and pragmatisms is unavoidable within society, including the Banjarese.

Secularism which puts more importance on profane worldly affairs over sacred affairs and the hereafter life is materialistic in nature. For the proponents of secularism there is no such spiritual consideration, all other useful things are here and now. The same is also true with the proponents of pragmatism. Anything that is practically beneficial to themselves regardless of negative impacts on others is considered as truth. While secularism produces people who deny believing the hereafter, pragmatism produces people having no integrity.

The impact of the infiltration of these two ideologies in a society is that people will adopt individualistic and competitive culture. This phenomenon now can be seen in the Banjarese society who used to be very appreciative towards spiritual and Islamic values.

The development of science has replaced superstitious and religious belief. Secular and pragmatic cultures infiltration comes along with the advance and development of science and technology. AB Shah (1986: 12) stated, science has been able to liberate man from all-God world views. Primitive people, as well as religious people, used to believe that nature, including the evolution of sun and moon, is all but the works of God. The advance of science and technology dictates that it is the laws of science that make all of these things in nature happen. Developments in science step by step replace superstition and religious position. Science and technology can also replace ideology embraced. Other ideologies as well as religion considered inhibitor for the attainment of progress and prosperity, so causing conflicts (Jacob, 1988: 9). As a result, more people now feel less bound by religion.

In this case, MUI (Indonesian Council of Ulama, 2011: 5), described: 
"On the other hand, the current Indonesian Muslims facing severe global challenges. These challenges include the ideology of liberalism-capitalism rooted in secularism with the political system and the economic systems are often forced prevailing land of many other states, the advancement of knowledge and technology that could break the standard of ethics and morals..."

\section{E. Technology and the Collapse of Civilization}

The essence of technology was originally to help people change the environment for the benefit of human life. The development and advancement scientific discoveries and inventions lead to more sophisticated technology. These developments in turn cause people to hardly control their own creations.

"Science and technology is growing and expanding rapidly exceeding the absorptive capacity of the human brain, that men are no longer able to understand the whole products of science regardless of the fact that man has already used it. Science and its products has even become the object itself. Human and nature are fragmented by science. At first man with science and technology wanted to conquer the nature up to a certain extent, but he forgot that he himself is part of nature and he is possessed by science" (MUI, 2011: 9).

Now technology is on its third phase, the peak stage. In the first phase, during the Stone Age man directly used techniques from natural materials. In the next phase, man were able to create things out of natural, while in the third pase man have invented sophisticated mechanical technology, and has brought about machine civilization (Adisusilo JR , 1983: 102-103).

A. Fatih Syuhud (2005), suggests that modern (especially transportation and communication) technology has brought about free transcontinental communication. It has shrunk planet earth to a global village, where everyone can access information almost instantly. This technology can be used as a very powerful instrument in the hands of peoples or groups to embed or undermine moral values, to influence or control of a person's thought patterns by those who have authority over 
the media. The real problem lies in those who control the global communications. They have extreme differences in perspective and alien to the criteria of Islam in giving moral values; between good and bad, the real truth and the artificial.

In the meantime the television media, as a product of modern technology and has the most far-reaching socio-psychological impact, is substantially influential on the audience. Several studies have shown the relationship between television viewing with aggressive behavior (Huismon \& Eron, 1986; Wiegman, Kuttschreuter \& Baarda, 1992), with an attitude of anti-social (Hagell \& Newburn, 1996), with an attitude of contented life without hardwork (Selnon \& Reynolds, 1984 ), with lifestyle trends (Henry \& Patrick, 1977), with racial attitudes (Zeckerman, Singer \& Singer, 1980), the tendency on sexual preference (Silverman - Watkins \& Sprafkin, 1983), awareness of sexual attraction (Tan, 1979), stereotypes of sexual roles (Durkin, 1985), with suicide (Gould \& Shaffer, 1986), and identification with characters on television (Shaheen, 1983).

On the one hand, some other studies show some promising effects of television, such as the awareness of all the events happening around the world (Cairn, 1990), awareness of rights and obligations as citizens (Conway, Steven \& Smith, 1975), increasing knowledge of geography (Earl \& Pasternack, 1991), increased knowledge about political issues (Furnham \& Gunter, 1983), being pro-social (Gunter, 1984). On the other hand, it should be noted that since the introduction of television with its all various channels offering a variety of programs, Muslims have only been the customer, while Westerner (read, non-Muslim) is in control.

\section{F. Strengthening the Spiritual Culture}

The above paragraphs ascertain that spiritual culture must be regarded as basic foundation of material culture development especially in views of inspirational, foundational, and orientation functions.

Spiritual culture can be easily related with and found in religion. What is meant by religion in this context is in line with what Nurcholish Madjid suggested that it is not the religion as a reality (practiced) in 
society or in its sociological sense, rather it is religion in its true sense which is deep and universal. The followings are some criteria of religion suggested by Madjid (1987: 154-155):

1. The need for belief in God with all its attributes;

2. Personal and intimate relationship with God;

3. The doctrine of the social function of wealth: the purpose of life is not the accumulation of wealth but in how it is used for our fellow humans;

4. Firmed recognition of things that cannot be approached or perceived empirically or inductively, but by deductively - "belief";

5. Belief in the existence of another life after historical life (the world).

Indeed, according to Jujun S Suriasumantri (1987: 123), religion would give a moral basis for scientific axiology.

Spiritual culture will lead the people of Banjar to become a man of integrity, faith and personality, and in turn will be able to exercise the soft dimension of the human resource from generation to generation that will play a role in future development.

Therefore, it is necessary to consider soft dimension of skills such as orientation, motivation, values, and attitude in human resource development. Of course this emphasis on the soft dimension should not disregard the hard dimensions which include acquisition of knowledge, skills and competence or other skills of the human resources. It certainly starts with the strengthening of spiritual culture on top of material culture.

\section{G. Spiritual Culture and Educator}

The term educator is difficult to track in the early development of society or the beginning of the founding of the kingdom of Banjar (16th century). Those who were instrumental in enlightening and educating the public were better known as scholars (ulama) in various names respective to their scholarship.

Alfani Daud citing Rass (1968: 460), states that there was not much information about the religious positions the Sultanate of Banjar, both during the reign of sultan Suriansyah and subsequent sultans. Hikayat 
Banjar gives a title panghulu (headman), Khatib (preacher) and Khalifah (Deputy); sometimes also called tuan penghulu (master headman), tuan khatib (master preacher) and tuan khalifah (master deputy), probably meant that the holder of such titles are those who already went to Hajj. Headmen was under Mangkubumi (high administrator) whose duties are religious affairs and (Islamic) law enforcement (Daud, 1997: 55).

At the Sultanate of Banjar, a position of mufti (advisor, counselor on religious affairs) was formalized. The Sultan was considered as the topmost authority of all religious officials. Under the sultan was mufti whose authority covers all religious officials in the territory of the empire and acted as the supreme judge. As the supreme judge, mufti supervised over all courts within the territory of the empire. The acting judge in the capital, whose main task was to settle daily disputes and affairs, was a kadi (obove the mufti); as the first kadi also appointed a descendant of Sheikh. Predictably, both mufti and kadi were leaders or officials of the grand mosque located in the capital city. A kadi, due its position in the capital might also have authority over judges at the regional level. The religious officials at Lalawangan level (distircts) was called penghulu (headman), whose authority includes the management of the mosque in his respective town, acting as a judge and supervisor over other lower officials in his respective jurisdiction. A penghulu was helped by a khalifah (deputy), whose main task was to represent the penghulu, and act as judge in the absence of the penghulu. Replace their duties when unable (including the authority to justice). Religious officials at the village level were called vice headman. His special authority was administrative affairs dealing with marriage (marriage contract in Islam) and divorce for village residents (Daud, 1997: 56-57).

As for the scholars (ulama) who are closer to the task of teaching and educating people in Banjarese society range from tuan guru (grand teacher), guru and fakih (grand or master teacher-cum-jurist), and guru. Guru (teacher) is for the scholars who have not performed the hajj pilgrimage, while Tuan Guru refers to those how have done so. The Fakih is a scholar whose specialization is Islamic jurisprudence. In some places, 
the term Fafakihan (quasi jurist) designates a scholar who is by the society as an expert in Islamic jurisprudence, regardless of neither his lack of understanding of the subject matter, nor his lack of ability in Arabic grammar. His expertise in Islamic jurisprudence is due to his intensive study with some ulama and did so in Malay language written in Arabic script (See Buseri, 1986: 27). The older the grand master, the more respect he receives that the most respected tuan guru tuha (senior grand teacher) is added to his title.

Respect of the people towards the scholars is based on the breadth and depth of the knowledge the society assume the scholars to have. The broader and deeper people assume a scholar masters the subject matter, the higher he is spiritually regarded. Therefore, it is common that people regard such a scholar to possess some supernatural knowledge of the unseen.

To illustrate the practice of respecting scholars, let's take a closer look at the following example. A prominent scholar who attends to a social function such as thanksgiving will be approached by scholars of lesser reputation as well as by common people to greet and try to kiss his hand. Such practice of hand kissing as a sign of respect is also received by a tutor who teaches how to read the Holy Quran. A Scholar of less prominent and village chief or other guests who occupy the space around tawing halat (main interior wall) usually greet guests sitting around them only, while the other guests go around to greet all of guests who come first, especially those sitting in the tawing halat (main interior wall). To lead prayer and supplications, the most prominent scholars are usually given the honor to do so. In the case of such function is held by limited number of people in the neighborhood, the honor is given to the most religiously knowledgeable of the guests. Sometimes a scholar, who is given the honor to read the prayer, invites other scholars of less prominence to lead the function. This is perhaps to acknowledge this particular scholar that he is now of the same level with other greater scholars.

When seeing each other, a younger member of society is supposed to greet the older members first, let alone seeing a scholar unexpectedly one will have the rare opportunity to greet, shake hand, and kiss his hand. 
Even if they do not greet, by shaking and kissing his hand, if they happen to be at the side of the road chatting with friends, they will certainly stop talking for a while just to let the scholar by pass (Daud, 1997: 101-102). It is even becoming a respectful act of students of private Islamic schools to help scholar cultivate his farm land. Such action is considered an act of respect to their teacher.

Scholars in early years of the sultanate of Banjar serve a state role as court officials in on religious matters and were given full authority to administer religious courts, marriage, settle inheritance, propagation of Islam and education in general.

In the middle of the 16th century when Banjarese sultanate was established, there was no formal educational activity in the kingdom. In the early 17th century, Islamic education thrived. During this era, the Islamic education was primarily conducted informally by tuan guru (grand teacher). The teaching practice at this time was part of $d a^{\prime} w a$ (preaching) and education in the broader sense. There was no formal school, so the activities of teaching and instruction were held in mosques or in the scholars' houses. This continued on to the 19th century.

The oldest private educational institution in Banjarmasin is an "Islamic School" founded by an Arab organization, "Musaadatul Ikhwan" led by Ibrahim al-Mualla. Initially located in Jalan Antasan Kecil Barat, it then moved to Kampung Bugis Jalan Sulawesi in 1903 (Analiansyah, et.al.: 2007: 25). Following this first Islamic school other schools sprung. On July 14, 1914 Madrasah "Imad Al fi Ta'limil Aulad Darussalam" in Martapura was established; in 1916 Kandangan Branch of Syarikat Islam built a function hall serving as meeting and learning place. The hall was called "Islamic Studies Club" or simply "Kalap". After 15 years since its establishment, this Kalap Islamic school was the village of Pandai Kandangan, from which the name Pandai Islamic School is taken. In 1924 an Islamic school was established. After a series of transformations, the school is now well-known as Ma had Rasyidiyah. In 1930s, Musyawaratut Thalibin founded several madrasahs in the former Banjarese sultante regions such as in Wasah, Padang Batung and Angkinang (HSS District), 
in Alabio and Amuntai (HSU District); in Kelua (Tabalong District). In 1934 a separate foundation established Madrasah Islamiah in Pantai Hambawang (HST District), in the same year the school union was formed under the name "Persatuan Perguruan Islam", Islamic School Union, (PPI). In 1925 a branch of Muhammadiyah was founded. In 1928 this Muhammadiyah branch founded an Elementary school of Muhammadiyah (volks school). In 1933 a branch of Nahdlatul Ulama (NU) was established. This NU branch also founded a school in Alabio (See: Full description on Analiansyah et al., 2007: 26-33).

In addition to the development of some madrasahs which are converted to pesantrens, new pesantrens (Islamic boarding schools) are also established like Al-Falah in Banjarbaru, Darul Hijrah in Martapura, and Darul Isiqamah in Barabai, and so forth. Besides the transformational development of Islamic schools, the meaning term 'educator' also changed. During the Dutch colonial era, prominent and knowledgeable Islamic scholars who were well-informed about Islamic classical books were regarded as educator. Being literate and well-versed in the classical books is the main characteristic of Banjarese scholars. The scholars' literacy and mastery of the contents of classical books earn them respectable religious and social position.

Other characteristic of scholars being their personal integrity and consistency as well as dedication in practicing Islamic principles and preach them to their people. These scholars serve the function of role model and man of knowledge to refer to for almost all matters of life.

In line with the establishment of madrasahs, the term educator also changes over time. Ustadz (male) and ustadzah (female) is now common use to refer to teachers in in pesanteren, and guru for teachers of madrasah. High literacy in classical books is a must for ustadz and ustadzah teaching in pesantrens, but not for guru teaching in madrasah. The latter, however, has formal prerequisite instead, that is having the qualification of at least graduating from undergraduate program. This is to meet specific requirement from the government as stated in law number 14/2005 on Teachers and Lecturers. 
However, scholars who teach some kind of religious study circles, which are termed as majlis ta'lim (study group), in mosques and prayer houses, are supposed to be literate and master the contents of the classical books, especially those pertaining to Islamic jurisprudence. As circumstances and need arose, some of these scholars engage in political activities as one study confirms the following names (See on TIM Peneliti: 1993: 15-60):

1. Tuan Guru H Akhmad Abdul Hamid (1903-1967) founder of the Madrasah Irtiqaiyah in Pemurus (1930) is known as a figure of Masjumi, and was once arrested by the Dutch in 1944;

2. Tuan Guru H Hanafi Gobit (1914-1990) the initiator of the establishment of SMIP (1946), and a co-founder of IAIN Antasari (1964), member of the Council of Banjar (1948-1950), member of the Constituent Assembly (1955-1959), a member of the Peoples' Assembly (1977-1982);

3. Tuan Guru H Jamaluddin, founder Madrasah Darussalam Martapura (1914), founder and Chairman of the Party of Islamic Union of South Kalimantan;

4. Tuan Guru Abdul Kadir Sheikh Hasan, the founder of NU (1928) and was a member of DPRGR of South Kalimantan Province (19661972);

5. Tuan Guru H Zafry Zamzam (1908-1972). 1931 active at the Union of Nations of Indonesia (PBI), member of the Islamic Party of Indonesia (PII), member of KNIP representing Kalimantan, member of Parliament (1950) and member of MPRS representing functional groups of scholars;

6. Tuan Guru H Kasyful Anwar, activist of Indonesian Muslim Union (SERMI), active in Masjumi, served as member of DPRDS, the 1958-1964 terms Regent of HSS;

7. Tuan Guru Haji Mansur Islmail (1905-1983) scholar Barabai, Parindra party activists under the leadership of Abd Kahar Mazakkir, active member and personnel of party SERMI Barabai branch, and once a member of Parliament. 


\section{H. Conclusion}

The long history of Banjarese culture, harmonious relationship between man, as a creator of culture, and nature, and God the creator of the universe has always been there. This cultural pattern is clearly of spiritual culture, which support and guard the material culture.

Spiritual culture as the foundation and referent of Banjarese material culture is in line with the spirit of Islamic teachings which dictate that the hereafter life is better than the worldly life. That is why the Banjarese follow the tenet of their spiritual culture which says "worldly life is important, but the hereafter is more important".

Building and fostering the spiritual culture in order to make a prosperous society requires not only rational approach, but also positivistic, phenomenology, and transcendental approaches.

The Sultanate of Banjar should continue to raise awareness that the sultanate is very attentive to and prioritize the spiritual culture. This is to give more meaning to the development of the material culture in many aspects of life. The sultanate should thrive to incorporate programs that strengthen this spiritual culture.

The role of educators, especially the scholars, the tuan guru, are still very much needed by today's society.

\section{Bibliography}

A.B. Shah. (1986). Metodologi Ilmu Pengetahuan, Yayasan Obor In $\neg$ donesia, Jakarta.

Adisusilo JR, Sutarjo. (1983). Problematika Perkembangan Ilmu Pe-ngetahuan, Yayasan Kanisius, Yogyakarta.

Analiansyah, et.al. (2007). Aspirasi Pendidikan Masyarakat Banjar, Antasari Press, Banjarmasin.

Buseri, K. (2015). Epistemologi Islam dan Reformasi Wawasan Pendidikan. Jurnal Ilmiah Peuradeun, 3(1), 77-102.

Buseri, Kamrani. (1986). Gagasan Tentang Pendidikan di Kalangan Orang Banjar Dan Penerapannya Pada Tiga Lembaga Pendidikan Swasta Agama. (Research Report), IAIN Antasari, Banjarmasin, 1986. 
Dahlan, Bayani (Ed.). (2009). Ulama BanjarE Karya-Karyanya, Antasari Press Banjarmasin.

Daud, Alfani. (1997). Islam dan Masyarakat Banjar Diskripsi dan Analisa Kebudayaan Banjar, PT Raja Grafindo Persada, Jakarta.

Faruqi, Y. M. (2015). Role of Muslim Intellectuals in the Development of Scientific Thought. Jurnal Ilmiah Peuradeun, 3(3), 451-466.

Jacob,T. (1988). Manusia Ilmu dan Tehnologi, Pergumulan Abadi dalam Perang dan Damai, Tiara Wacana, Yogyakarta.

Madjid, Nurcholish. (1987). Islam, Kemoderanan dan Keindonesiaan, Mizan, Bandung.

Sekretariat Majelis Ulama Indonesia (MUI) Pusat. (2011). Pedoman Penyelenggaraan Organisasi Majelis Ulama Indonesia, Edisi Revisi 2011 (Hasil Rakernas MUI Tahun 2011), Jakarta.

Suriasumantri, Jujun S. (1987). Filsafat Ilmu Sebuah Pengantar Populer, Pustaka Sinar Harapan, Jakarta.

Syuhud, A. Fatih. (2005), Tantangan Pendidikan Islam di Era Globalisasi September 6, 2005, Posted by Fatih in Artikel Opini, Islam. trackback Catatan: Tulisan ini dimuat di Jurnal VISI, PPI-India dan Sidogiri.com)

Tan, C. (2015). Educative Tradition and Islamic School in Indonesia. Jurnal Ilmiah Peuradeun, 3(3), 417-430.

Tim Peneliti Fakultas Tarbiyah Banjarmasin. (1993). Elite Muslim di Kalimantan Selatan (Studi Gerakan Elite Muslim di Bidang Pendidikan 1900-1950), Institut Agama Islam Negeri, Fakultas Tarbiyah Banjarmasin.

Tylor, Edward B. (1920). Primitive Culture, Sixth Edition, J. Murray, London.

Yusof, Abd. Aziz. (2005). Human Resource Management The Soft Dimension, Pearson Printice Hall, Selangor, Malaysia. 